logos_i_ethos_2014_1_(36), s.189-207

\title{
Paul Ricoeur
}

\section{Lectio magistralis ${ }^{1}$ Uniwersytet w Barcelonie, 24 kwietnia 2001 roku}

Paul Ricoeur (1913-2005) należy
z cała pewnościa do grupy filozofów ty-
leż wybitnych, co wszechstronnych. Pod tym pierwszym określeniem należy rozumieć fakt, że jego filozofia stale jest obecna we wspótczesnych debatach filozoficznych. Trudno sobie wyobrazić dzisiaj refleksję o człowieku bez odwołania się do Ricoeura, do jego nowej koncepcji podmiotowości, nowego rozumienia etyki, działania, opowiadania, które domaga się interpretacji czy odpowiedzialności. Jednocześnie jego myśl nie poddaje się łatwym klasyfikacjom - stad to drugie określenie - $i$ czerpie praktycznie $z$ całej tradycji filozoficznej, od Arystotelesa, przez Kartezjusza, Kanta, Hegla, aż po Freuda, strukturalistów, postmodernistów i anglosaska filozofię analityczna, a wszystkie te watki spojone zostaja jednym zasadniczym pytaniem: „Kim jest człowiek?”.

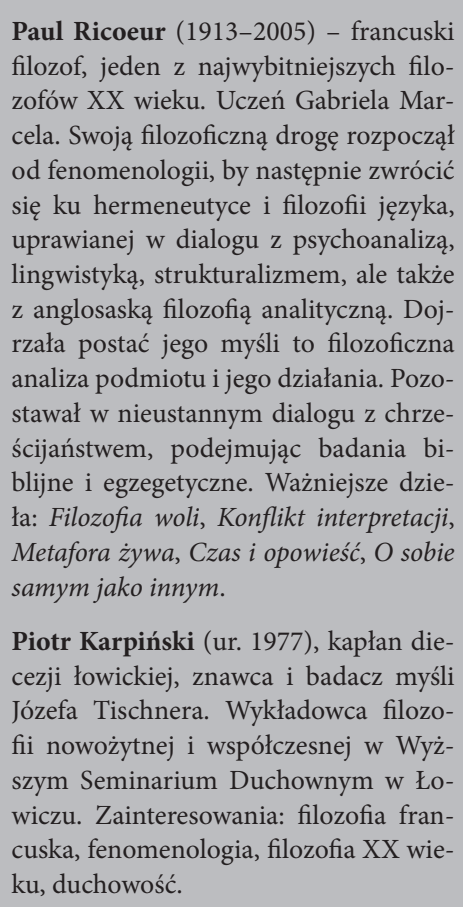

Paul Ricoeur (1913-2005) - francuski filozof, jeden z najwybitniejszych filozofów XX wieku. Uczeń Gabriela Marcela. Swoją filozoficzną drogę rozpoczą od fenomenologii, by następnie zwrócić się ku hermeneutyce i filozofii języka, uprawianej w dialogu z psychoanalizą, lingwistyką, strukturalizmem, ale także $\mathrm{z}$ anglosaską filozofią analityczną. Dojrzała postać jego myśli to filozoficzna analiza podmiotu i jego działania. Pozostawał $\mathrm{w}$ nieustannym dialogu $\mathrm{z}$ chrześcijaństwem, podejmując badania biblijne i egzegetyczne. Ważniejsze dzieła: Filozofia woli, Konflikt interpretacji, Metafora żywa, Czas i opowieść, O sobie samym jako innym.

Piotr Karpiński (ur. 1977), kapłan diecezji łowickiej, znawca i badacz myśli Józefa Tischnera. Wykładowca filozofii nowożytnej i współczesnej w Wyższym Seminarium Duchownym w Łowiczu. Zainteresowania: filozofia franku, duchowość.

1 Podstawa przekładu: Lectio magistralis de Paul Ricoeur, Université de Barcelone, 24 avril 2001, [w:] D. Jervolino, Paul Ricoeur. Une herméneutique de la condition humaine, Paris 2002, s. 75-91. W oryginalnym tekście Ricoeur nie zamieścił żadnych przypisów. Wszystkie przypisy w niniejszym tłumaczeniu pochodzą od tłumacza i dotyczą bądź wskazówek bibliograficznych odnośnie do dzieł Ricoeura, bądź trudniejszych kwestii językowych. 
Do myśli danego filozofa można podchodzić na różne sposoby. Można $z$ jednej strony wikłać się $w$ szczegółowe analizy i badać dokładnie meandry jego filozofii, $i$ choć jest to niesamowita praca, to jednak dostępna raczej wąskiemu gronu specjalistów. $Z$ drugiej strony istnieje ryzyko poprzestania - w najlepszym przypadku - na kilku encyklopedycznych wiadomościach. Drogę środka wyznacza całościowe, ale i syntetyczne spojrzenie na myśl danego filozofa, próba objęcia całego rozwoju jego filozofii jakby „z lotu ptaka”. Ponizsszy tekst jest zaproszeniem do pójścia ta właśnie droga środka.

Paul Ricoeur został w kwietniu 2001 roku zaproszony przez Uniwersytet w Barcelonie do wygłoszenia specjalnego wykładu, tzw. „lectio magistralis". Nazwa ta dokładnie oznacza wykład mistrza, uznanego autorytetu $w$ danej dziedzinie, na dowolny temat. Ricoeur, już wówczas bardzo zaawansowany wiekiem, zechciał zaprezentować rozwój całej swojej myśli filozoficznej, nakreślić niejako swoją biografię intelektualną. Dzięki temu otrzymujemy wspaniała autoprezentacje, pozwalająca zapoznać się $z$ podstawowymi dziełami i zawartymi weń koncepcjami autora.

Tekst wykładu nie znalazł się w żadnej książe Ricoeura. Autor dokonał jego autoryzacji $i$ wyraził zgodę na zamieszczenie go jako dodatku do książki Domenica Jervolina, poświęconej myśli hermeneutycznej Ricoeura.

Początek moich filozoficznych zainteresowań datuje się na ostatnią klasę szkoły średniej. Od siedemnastego roku życia, dzięki pewnemu niezapomnianemu profesorowi, byłem konfrontowany z wymaganiami rygoru myślowego i odwagi intelektualnej, których dłużnikiem czuję się na zawsze: „Nie uciekać przed trudnościami, lecz mierzyć się z nimi” - to była jego maksyma.

Kilka lat później miałem szczęście studiować u filozofa Gabriela Marcela, równolegle do oficjalnych studiów na Sorbonie. W odróżnieniu od znakomitych wykładów z historii filozofii greckiej, klasycznej i nowożytnej, które oferowało nauczanie publiczne, mój pierwszy 
mistrz proponował wolne badanie trudnych problemów z pogranicza refleksji i życia.

W tym samym roku, w którym także odbył się państwowy egzamin na agregację ${ }^{2}$ zamykający lata moich studiów, zostałem zapoznany z już wydanymi dziełami Husserla, założyciela kierunku fenomenologicznego, i z jego dążeniem do ścisłego i dokładnego opisu fenomenów psychicznych. Z wpływem Marcela i Husserla łączy się także, z czasów mojej niewoli w Niemczech jako więźnia wojennego, wpływ Karla Jaspersa, którego stanowisko filozoficzne zawarte jest w wielkiej pracy zatytułowanej Philosophie. W ten sposób, wychodząc z II wojny światowej, zostałem wyposażony na drogę kariery i osobistego dzieła, pozostając pod potrójnym patronatem Gabriela Marcela, Karla Jaspersa i Edmunda Husserla.

Początkowo nauczałem w szkołach średnich, a następnie od roku 1948 na poziomie akademickim w Katedrze Historii Filozofii Uniwersytetu w Strasburgu. Dziesięć lat strasburskich (1948-1958) okazało się dla mnie bardzo szczęśliwymi. Wybór Sorbony w 1958 roku zainaugurował długi okres nauczania i badań dzielony między Francję i USA (Yale, Montreal, Columbia, następnie Chicago w ciągu 24 lat). Mogę dziś powiedzieć, że byłem nauczycielem spełnionym.

Moim pierwszym wkładem w filozofię, poza dwoma dziełami poświęconymi myśli moich pierwszych mistrzów, Gabrielowi Marcelowi i Karlowi Jaspersowi $\left(1947^{3}, 1948^{4}\right)$, było opracowanie fenomenologicznej filozofii woli: Le volontaire et l'involontaire (1950) ${ }^{5}$. Opisywałem w nim, podobnie jak Merleau-Ponty w Phénoménologie de la perception, podstawowe fenomeny ze sfery praktycznej: zamiar, zwyczaj, emocję i, po raz pierwszy, nieświadomość, nazywaną tutaj tym, co

\footnotetext{
Agregacja to we francuskim systemie edukacyjnym egzamin państwowy, wymagany do objęcia stanowiska wykładowcy jakiejś dyscypliny. Często ma miejsce jeszcze przed doktoratem.

P. Ricoeur, Karl Jaspers et la Philosophie de l'existence, en collaboration avec M. Dufrenne, Paris 1947.

4 Tenże, Gabriel Marcel et Karl Jaspers. Philosophie du mystere et philosophie du paradoxe, Paris 1948.
}

Tenże, Philosophie de la volonté: I. Le volontaire et l'involontaire, Paris 1950. 
absolutnie mimowolne (l’involontaire absolu) ${ }^{6}$, by odróżnić ją od oporów i zachęt, które wola napotyka na poziomie wyraźnej świadomości. W latach 60. przez długi czas zajmowałem się nieświadomością. Ale wcześniej usiłowałem poszerzyć pole moich badań nad wolą, biorąc pod uwagę dwuznaczne doświadczenia dotyczące złej woli, chętnie przypisywane ciemnym mocom. Od tego czasu datuje się moje zainteresowanie wyrażeniami symbolicznymi, mitycznymi i poetyckimi, w które ludzkość wpisała swoje doświadczenie zła moralnego. Od tej wyprawy w najbardziej niezwykłe regiony języka datuje się druga część mojej filozofii woli: Finitude et culpabilité (1960) ${ }^{7}$. Dzieło zawiera trzy poziomy: o pierwotnych symbolach zła (macierzyste obrazy winy, jak: upadek, brzemię, zboczenie), następnie o wielkich mitach o pochodzeniu zła, w końcu - o wielkich spekulacjach na temat stosunku między skończonością a winą.

W istocie problem złej woli i zła zmusił mnie do uzupełnienia fenomenologicznej metody opisu istotnościowego o metodę interpretacji, zapożyczoną z całkiem innej tradycji niż fenomenologia Husserlowska, a mianowicie z filologii klasycznej, egzegezy tekstów świętych, jurysprudencji, kryjących się pod nazwą hermeneutyki. Wyłoniła się przy tym nowa problematyka, w której zapośredniczenie w języku i jego wielkich jednostkach narracyjnych, jakimi są teksty, narzucało także swoje pośrednictwo pomiędzy żywym doświadczeniem a refleksją filozoficzną. Problematykę tę można streścić w dwóch formułach, zapamiętanych przez wielu czytelników prac z tamtego okresu: „symbol daje do myślenia” oraz „więcej wyjaśniać, by lepiej zrozumieć”. Pierwsza z tych formuł dobrze podsumowała filozofię woli, druga zaś otwierała nową erę

${ }^{6}$ Termin l'involontaire jest trudny do oddania po polsku. Chodzi o rzeczownik utworzony od przymiotnika involontaire, czyli „niechciany, mimowolny, nieumyślny, bezwiedny”. L'involontaire to zatem obszar niezamierzonych działań człowieka, niezależnych od aktów świadomościowych, czyli myślenia, woli, sądu. W tym sensie Ricoeurowskie l’involontaire jest niemal synonimicznie bliskie Freudowskiej nieświadomości (l’inconscient).

7 P. Ricoeur, Philosophie de la volonté: II. Finitude et culpabilité: 1. L'homme faillible, Paris 1960; 2. La symbolique du mal, Paris 1960. Po polsku ukazała się jak dotąd tylko druga część drugiego tomu Filozofii woli: Symbolika zła, tłum. S. Cichowicz, M. Ochab, Warszawa 1986. 
dla moich późniejszych prac, łącząc ściśle dwa podejścia, często uznawane za wrogie wobec siebie - wyjaśnianie, które zbliża nauki humanistyczne do nauk przyrodniczych, i interpretację, która nie kończy się na obserwacji empirycznej, lecz otwiera przestrzeń dyskusji pomiędzy konkurencyjnymi interpretacjami, zastosowanymi do wielkich tekstów naszej kultury.

Tej konfrontacji pomiędzy sprzecznymi interpretacjami poświęciłem książkę De l'interprétation. Essai sur Freud $(1965)^{8}$. Podjąłem w niej na nowo zagadnienie nieświadomości, które napotkałem pierwszy raz u mojego pierwszego mistrza filozofii, a którym zajmowałem się systematycznie pod nazwą „to, co absolutnie mimowolne” (l'involontaire absolu) w mojej filozofii woli. Nie chodziło o „to, co mimowolne” jako "powrót nieświadomości” (linconscient), ale o nośnik sensu, domagający się odkodowania podwójną drogą: wyjaśniania (lexplication) w kategoriach popędu (pulsion) oraz interpretacji w kategoriach wieloznaczności, jak to widzimy w snach, symptomach, pomyłkach, wyrażeniach mitycznych czy poetyckich. Usiłowałem więc pogodzić dwa podejścia - z grubsza "naturalistyczne” i ,hermeneutyczne” - stwierdzając, że nieświadomość (linconscient) jako przedmiot badań jest punktem, w którym przecinają się „siła” $i$,sens”, „popęd” i „przedstawienie”. Z tego powodu zmuszony byłem podważyć te filozofie świadomości, które pojawiły się od Kartezjusza, a do których przynależała ciągle fenomenologia Husserla, uprawiana zresztą przeze mnie w moich pierwszych pracach. W tym oceanie niepewności poszukiwałem odpowiedniego przewodnika po złożonym funkcjonowaniu języka i w taki sposób przesunąłem się stopniowo od filozofii działania do filozofii języka, zanim, dla równowagi, powróciłem do sfery praktycznej.

Była to zresztą epoka zwrotu lingwistycznego (linguistic turn) na wszystkich frontach filozofii. Wydaje się, że zostałem zachęcony do pójścia w tym kierunku przez spotkanie anglojęzycznej filozofii analitycznej, do czego miałem okazję podczas coraz częstszych i dłuższych pobytów

8 Tenże, De l'interprétation. Essai sur Freud, Paris 1965. Wydanie polskie: O interpretacji. Esej o Freudzie, tłum. M. Falski, Warszawa 2008. 
na uniwersytetach amerykańskich od końca lat 50., a od roku 1967 już stale na Uniwersytecie w Chicago na Wydziale Religii, Filozofii i Nauk Społecznych. W latach 1970-1980 język stał się miejscem wszelkich konfrontacji. Nie tracąc związków z fenomenologią i hermeneutyką, skoncentrowałem się na twórczym aspekcie języka: w jaki sposób tworzą się nowe znaczenia? Moglibyśmy nazwać tę kwestię problemem wyobraźni semantycznej (l'imagination sémantique), przez wyobraźnię rozumiejąc nie tyle umysłowe przedstawianie sobie uprzedniego doświadczenia percepcyjnego, ile uschematyzowanie pewnej rozumnej reguły, na sposób słynnego „schematyzmu” w rozumieniu Kantowskim.

Na tym obszernym polu wyobrażenia semantycznego opracowywałem dwie ściśle określone dziedziny: z jednej strony, powstawanie języka poetyckiego w obrębie wyrażeń metaforycznych, dobrze znanych z wielkiej tradycji retorycznej starożytności i nowożytności, z drugiej strony, kształtowanie się języka narracyjnego w nurcie lingwistyki strukturalnej, zastosowanej do opowieści. La métaphore vive $(1975)^{9}$ omawia pierwszą dziedzinę, Temps et récit I, II, III ${ }^{10}$ (1983-1985) drugą.

Obydwie serie studiów przyczyniły się do zbadania tego, co nazywałem innowacją semantyczną (l'innovation sémantique), tworzeniem sensu na bazie trzech składowych języka: słowa, zdania i tekstu (w sensie dyskursu obejmującego dwie poprzednie jednostki). La métaphore vive dała mi możliwość prześledzenia historycznej drogi, poczynając od Retoryki i Poetyki Arystotelesa, poprzez retorykę starożytną i nowożytną, dochodząc do najbardziej skomplikowanych analiz kombinatoryki semiotycznej. Na końcu tej drogi zaryzykowałem badania w kierunku ontologii. Czyż język poetycki, tworząc metaforycznie nowy sens zdaniowy i tekstowy, nie naprowadza na takie obszary doświadczenia ludzkiego, które powinny być dostępne jedynie dla języka analogicznego,

9 Tenże, La métaphore vive, Paris 1975.

10 Tenże, Temps et récit $t$-1: L’intrigue et le récit historique, Paris 1983; Temps et récit $t$-2: La configuration dans le récit de fiction, Paris 1984; Temps et récit t-3: Le temps raconté, Paris 1985. Wydanie polskie: Czas i opowieść, tom 1: Intryga i historyczna opowieść, tłum. M. Frankiewicz, Kraków 2008; Czas i opowieść, tom 2: Konfiguracja w opowieści fikcyjnej, tłum. J. Jakubowski, Kraków 2008; Czas i opowieść, tom 3: Czas opowiadany, tłum. U. Zbrzeźniak, Kraków 2008. 
połączonego ściśle z językiem apofatycznym (mówiącym czym byt nie jest): „byt-jako” (lêtre-comme), w czym zawiera się geniusz metafory? Lecz te ryzykowne sugestie chwilowo zawiesiłem, by zwrócić się w stronę innego problemu innowacji semantycznej, jakim jest opowiadanie. Za przewodniczkę posłużyła mi tu Arystotelesowska teoria intrygi (mythos, baśń), zawarta w jego Poetyce, i przy pomocy także współczesnej narratologii sformułowałem koncepcję "konfiguracji narracyjnej” (configuration narrative), by uzmysłowić wielość sposobów opowiadania (mettre en intrigue) jednocześnie o wydarzeniach, akcji i osobach. Na bazie tej fundamentalnej struktury będę badał wielkie pola uprawiania narracyjności: zwykłą rozmowę, relacje historyków, fikcje greckich tragedii i współczesnych powieści, utopie politycznych marzycieli.

W tym samym czasie, kiedy badałem wielką strukturę języka - opowiadanie - przecierałem także szlak do starożytnego i szacownego problemu czasu: opowiadanie rozwija intrygę w czasie; dokładniej mówiąc, ono wyraża czas akcji i namiętności, czas wydarzeń i uczuć, tworząc czas drugiego poziomu, czas, który intryga rozwija między początkiem opowiadania i jego końcem (zakończeniem lub jego brakiem). Z kolei te czasowe struktury dają podstawę do tego, co proponowałem nazywać „narracyjną tożsamością jednostek bądź wspólnot”. Tożsamość narracyjna różni się od tożsamości biologicznej, wyznaczonej przez kod genetyczny każdego człowieka, niezmiennej od momentu poczęcia do śmierci, jak i od innych cech indywidualnych (linie papilarne, podpis, cechy twarzy etc.), i nie ma żadnej innej kontynuacji, jak tylko historię życia: opowiadanie, mówi filozof, wyraża "kto” akcji; jedynym stałym elementem tożsamości narracyjnej może być tylko obietnica, dzięki której trwam w stałości słowa danego i dotrzymanego. Ta tożsamość narracyjna ma swoje pułapki, swoje zwyczaje i nadużycia, swoje karykatury, jak to widać w hierarchii ludów i narodów, gdzie służy ona za porękę strachowi, nienawiści, przemocy, autodestrukcji. Ale opowiadanie ma jeszcze inne funkcje: jest ono narzędziem lingwistycznym, które pomaga uzgodnić czas kosmiczny, czas naturalnych przemian, z czasem psychologicznym, związanym z pamięcią i zapominaniem. Struktury opowiadania wpisują przeżyty czas psychologiczny w rytm zmian fizycznych za pomocą 
instrumentów mierniczych, takich jak zegar czy kalendarz. Jest to zasadnicze dla skali historii, opisywanej przez historyków, by te wielkie łączniki między czasem natury i czasem kultury pełniły swoją funkcję połączeń pomiędzy słowami i rzeczami, między ludzkością a siłami kosmicznymi; opowiadanie jest wielkim transformatorem sensu, działającym między wszystkimi poziomami rzeczywistości. Jest ono dziełem języka, osiągnięciem innowacji semantycznej.

Po wydaniu trzech tomów Temps et récit odpowiedziałem na zaproszenie wystosowane do mnie w 1986 roku, by wygłosić tzw. Gifford Lectures $^{11}$ na Uniwersytecie w Edynburgu. Poproszono mnie wówczas, by przedstawić syntezę moich prac. Pojawiło się zatem pytanie o jakąś jedność moich prac - jeśli nie systematyczną, to przynajmniej tematyczną - czterdzieści lat od moich pierwszych publikacji. Pytanie to było tym bardziej kłopotliwe, że uderzała mnie - o wiele bardziej być może niż moich czytelników - różnorodność podjętych tematów. Faktycznie każda książka rodziła się z jakiegoś określonego tematu: wola, nieświadomość, metafora, opowiadanie. W pewnym sensie jestem przekonany o konieczności rozproszenia pola refleksji filozoficznej, w zależności od wielości określonych pytań, domagających się za każdym razem odrębnego potraktowania wobec ograniczonych, choć dokładnych wniosków. W tym sensie nie żałuję, że największą część mojego dzieła poświęciłem na krążenie po problemach, które wyznaczają skończoną przestrzeń ich stawiania, ryzykując za każdym razem otwieranie badań w horyzoncie sensu, który pozostaje jedynie na marginesie omawianego problemu. Szło to wszystko pod prąd pragnieniu, by zaproponować mojemu audytorium jakiś klucz do lektury. Z próby tej zrodziło się dzieło Soi-même comme un autre $(1990)^{12}$. Wydawało mi się, że liczne problemy, którymi

11 Wykłady Gifforda (tzw. Gifford Lectures) to nazwa rocznej serii wykładów, dawanych przez wybitnych uczonych na kilku szkockich uniwersytetach, m.in. w Glasgow, Aberdeen czy właśnie w Edynburgu. Zostały one ustanowione w XIX wieku i stanowią jedno z bardziej prestiżowych wydarzeń szkockiego życia akademickiego. Ich celem jest promowanie i upowszechnianie studiów z zakresu teologii naturalnej, czyli poznania Boga, a także dialogu religii z nauką.

12 P. Ricoeur, Soi-même comme un autre, Paris 1990. Wydanie polskie: O sobie samym jako innym, tłum. B. Chełstowski, Warszawa 2005. 
zajmowałem się w przeszłości, mogą być pogrupowane wokół kwestii centralnej, która wypływa w naszym dyskursie z użytku, jaki czynimy z czasownika modalnego ,ja moge”" (je peux). Merleau-Ponty, przywołany powyżej przy okazji mojej pierwszej pracy, badał ten obszar przede mną. Dzieło, które pojawiło się w wyniku Gifford Lectures, jest rzeczywiście zorganizowane wokół czterech głównych użyć wyrażenia „ja mogę". Mogę mówić, mogę działać, mogę opowiadać, mogę być odpowiedzialny za swoje czyny, pozwalać je sobie przypisać jako ich sprawca. Te cztery kwestie dały się powiązać odpowiednio z filozofią języka, filozofią działania, teorią narracji i wreszcie z filozofią moralną. Poza tym każdy z tych czterech wielkich działów pozwalał się dalej dzielić według dwóch ujęć: analitycznego i refleksyjnego.

W ten sposób dotykając języka, mogłem poświęcić jeden rozdział na stanowiska strukturalne języka francuskiego i na stanowiska „analityczne" (w sensie, jaki temu słowu nadała filozofia angloamerykańska): zdanie, które można napisać na ścianie, jak twierdzi Frege, to model dla stanowiska obiektywnego, zewnętrznego, w którym sens semantyczny lub stylistyczny jest niezależny od jakiegokolwiek subiektywnego zaangażowania. Następnie jeden rozdział został poświęcony na podejście refleksyjne, w uznaniu dla współczesnych badań nad takimi aktami mowy (tudzież języka), jak obietnica, przykazanie, czy samo twierdzenie (l’assertion), które nie wymaga mniejszego osobistego zaangażowania, niż obietnica czy przykazanie: takie wyrażenia, jak „sądzę, że...”, „mogę zapewnić, że...", kryją się w podtekście najprostszych twierdzeń, wskazujących na stan danej rzeczy. Ta korelacja na poziomie języka pomiędzy podejściem analitycznym i refleksyjnym mogła posłużyć jako model dla podobnej korelacji w innych dziedzinach.

Co się tyczy możliwości działania (pouvoir-agir), to mogłem z jednej strony poruszyć teorię działania od strony przedmiotowej, na wzór D. Davidsona, łącząc działanie z wydarzeniem mającym miejsce w rzeczywistości fizycznej i pochodzącym od obserwowalnej przyczynowości psychicznej, z drugiej zaś strony, mogłem śledzić drogę interioryzacji, która prowadzi od działania-zdarzenia do działania-projektu i od przyczynowości obserwowalnej do przeżytej motywacji. 
Koncepcja „zdolności do działania” (capacité à agir) nadała w ten sposób praktycznemu „ja mogę” strukturę jednocześnie przedmiotową i refleksyjną.

Jeśli chodzi o możliwość opowiadania (pouvoir-raconter), udało mi się zintegrować wyniki moich wcześniejszych prac na temat opowiadania $\mathrm{z}$ obszernym kręgiem ludzkich możliwości. Z jednej strony odnalazłem ponownie przedmiotowe podejście strukturalizmu triumfującego $\mathrm{z}$ lat 70., $\mathrm{z}$ którym toczyłem batalie w szkicach zebranych pod tytułem Le conflit des interprétations (1969) ${ }^{13}$, a także podejście refleksyjne, które najlepiej wyraziło się w koncepcji tożsamości narracyjnej.

Pozostawało jeszcze czwarte główne użycie czasownika modalnego „ja mogę". Odnalazło ono swoje dokładne sformułowanie w koncepcji „przypisania” (imputabilité), która pozwoliła mi połączyć sferę moralną z praktyczną sferą ludzkich możliwości. Przez przypisanie (imputabilité) rozumiem zdolność do uważania siebie za księgowego (comptable) swoich własnych czynów; jak sugeruje to metafora rachunku (compte) - którą odnajdujemy w niemieckim Rechnung, Rechnungsfähigkeit, w angielskim account, accountability, byt ludzki jest zdolny do podejmowania działań na swój własny rachunek, do zdawania sprawy z nich przed sobą samym i przed drugim, i w ten sposób do uważania siebie za ich prawdziwego autora. Jedynie akty, których sprawstwo może być przypisane odpowiedzialnym podmiotom, mogą być zakwalifikowane moralnie jako dozwolone lub zabronione, dobre lub złe, sprawiedliwe lub niesprawiedliwe.

Zanim poruszę problematykę doświadczenia moralnego, chciałbym wskazać na jeszcze inną implikację pojęcia podmiotu, sformułowanego w tytule dzieła Soi-même comme un autre. Otworzył się nowy front badań, obok obszaru będącego efektem konfrontacji między ujęciem analityczno-obiektywnym i refleksyjno-subiektywnym, front pochodzący z rozróżnienia siebie (soi) i innego. Samo pojęcie siebie (soi) wydawało mi się różne od pojęcia ,ja” ( $m o i)$, nie tylko ze względu na

13 Tenże, Le conflit des interprétations. Essais d’herméneutique I, Paris 1969. Fragmenty dzieła ukazały się po polsku: Egzystencja i hermeneutyka. Rozprawy o metodzie, tłum. E. Bieńkowska, H. Bortnowska, S. Cichowicz i in., Warszawa 1985. 
swój niebezpośredni charakter refleksyjny, podkreślany na każdym etapie przez zapośredniczenie w języku, ale ze względu na swój charakter dialogiczny. Przeciwstawiałem się w taki sposób monologicznej, by nie powiedzieć solipsystycznej, interpretacji Kartezjańskiego cogito. Wyrażenie „ja myślę” jest od razu wyrażeniem jakiegoś „ja”, jakiegoś „ty”, jakiegoś „my”. Ta fundamentalna struktura dialogiczna potwierdzała się w każdym przedziale badań podstawowych możliwości, poczynając od poziomu języka. Mowa, w swojej najbardziej elementarnej postaci, na poziomie zdania, polega na tym, że ktoś - mówi coś - do kogoś innego - o czymś, co jest wspólnym punktem odniesienia; mowa jest skierowana do... Podobną strukturę dialogiczną można wyróżnić w obrębie działania: działanie jest działaniem z, działaniem przeciw, w kontekście interakcji, udramatyzowanym przez konflikt i przemoc; coś walczącego odciska swe piętno na tragedii działania, co w nieszczęściach XX wieku znalazło swój niezwykle przerażający wyraz. Opowieść odbija w swoich strukturach narracyjnych tę walkę w planie praktycznym: snucie intrygi (la mise en intrigue) organizuje, jako się rzekło wyżej, zarówno osoby ujęte w sytuacji konfliktu, jak i działania, które z kolei generują wydarzenia, snując wątek opowiadania. Są jeszcze opowiadania, które zapewniają doświadczeniu moralnemu jednocześnie unikalność i egzemplaryczność konfiguracji. Nie jest to jedynie doświadczenie czasu, który przez konfigurację narracyjną zostaje ponownie przedstawiony, ale doświadczenie moralne pod postacią tego, co później będziemy nazywali mądrością praktyczną. W ten sposób zgodność między refleksyjnością i obiektywnością analityczną ciągnie się przez wszystkie obszary doświadczenia ludzkiego. Zespół tych dwóch systemów tworzy sieć Soi-même comme un autre. Sobość (soi) nie dzieje się ani bez przedmiotowej projekcji, która wymusza zapośredniczenie w zewnętrzności, ani bez implikacji dialogicznej, która z kolei wymusza zapośredniczenie w „innym”, tym innym na zewnątrz, przedstawianym przez obcego, a czasem przez adwersarza.

$\mathrm{Na}$ boku tej ogólnej panoramy, którą właśnie naszkicowałem, pozostawiam trzy ostatnie rozdziały poświęcone doświadczeniu moralnemu, gdyż to je właśnie poddaję dziś poważnej rewizji, przedłużając je w różnych obszarach zastosowań. Pracę Soi-même comme un autre 
rozpoczynam od przedstawienia podstawowej teleologicznej koncepcji życia moralnego, jaką Arystoteles zawarł w Etyce nikomachejskiej, a z której zapożyczam pojęcie „etyki” rozciągnięte na wszelkie doświadczenie moralne bardziej spod znaku dobra aniżeli obowiązku, jak to jest w tzw. deontologicznych systemach moralnych, wykazujących związek $\mathrm{z}$ deon, czyli obowiązkiem.

Stoję na stanowisku, że to w głębokich strukturach rozumnego pożądania zarysowuje się dążenie etyki fundamentalnej, która za horyzont ma dobre życie (vivre-bien, la vie bonne). Schemat ten dominuje w starożytnych systemach moralnych, w których wartości są modelami doskonale zdolnymi wyznaczyć i ustrukturyzować dążenie do życia dobrego. Wzbogacam tę koncepcję etyczną, rozwijając dialogiczne i wspólnotowe komponenty dążenia do życia dobrego w horyzoncie szczęścia. Proponuję następującą formułę etyki: żyć dobrze, z innymi i dla innych, w sprawiedliwych instytucjach. Przejście pomiędzy etyką (teleologiczną) i moralnością (deontologiczną) wydaje mi się podyktowane sytuacjami konfliktowymi i sytuacjami przemocy, przywołanymi powyżej w kontekście teorii działania i teorii narracji. Przewodnikiem w badaniu poziomu czysto „moralnego” w doświadczeniu moralnym może być Kant. Zostaje zakwestionowane Kantowskie kryterium uniwersalizacji, według którego podmiot moralny przekonuje się o legalności, ważności swoich planów działań (co Kant nazywa maksymą postępowania). Trudności w stosowaniu tego kryterium uniwersalizacji maksym prowadzą od abstrakcyjnego poziomu obowiązku - od formalizmu imperatywu kategorycznego - do konkretnego poziomu mądrości praktycznej - decyzji w konkretnych, pojedynczych i niepewnych sytuacjach. W tym planie mądrości praktycznej odnajduję formuły rady, wspólnego zastanawiania się, podejmowania decyzji, to, co Arystoteles umieścił pod nazwą phronesis dojrzałego osądu, co Rzymianie przetłumaczyli jako prudentia, a co nie oddziela mądrości spekulacyjnej od mądrości praktycznej, podejmowanej przez człowieka mądrego - z krwi i kości. Do tej właśnie mądrości praktycznej odnoszę formy osądu moralnego w sytuacji, który napotykamy w etyce medycznej lub w etyce prawniczej, 
do czego za moment jeszcze powrócę. Ale teraz chciałbym przez chwilę zatrzymać się przy strukturze całego dzieła.

Chodzi o organizację tego, co ironicznie nazwałem moją „małą etyką", a co dzisiaj chcę poddać rewizji. Proponowałbym rozpocząć od poziomu normatywnego, na którym wyraża się sens normy i bycia zobowiązanym: jest to takie powszechne doświadczenie moralne, w którym stosunek do tego, co dozwolone i do tego, co zakazane, jest zarazem daną bazy normalnego życia, a jednocześnie nieustannym tematem pytań, kontestacji i rewizji. Są to wewnętrzne trudności naszego stosunku do strukturyzujących zakazów, które prowadzą nas do poszukiwania fundamentu dla naszych zobowiązań moralnych, zwłaszcza ujawniających się w porządku społecznym, bardziej radykalnego niż proste „musisz”. Takie badanie odsyła nas z powrotem do analiz Greków na temat pożądania, praktycznego namysłu, stosunku do praktyk poddanych próbie czasu i doświadczenia, słowem, do historii zwyczajów wziętych w ich wymiarze wspólnotowym. Jednakże ten powrót do etycznych źródeł moralności, to odwoływanie się „wstecz", do etyki „górnego biegu”, nie dałoby się sformułować - wszak powody działania są głęboko ukryte - bez zaprojektowania „do przodu” etyki stosowanej, etyki „dolnego biegu", gdzie konkretnie sprawdza się fundamentalne dążenie etyki "górnego biegu". Ta dyskusja pomiędzy etyką fundamentalną i etykami stosowanymi, przechodząc przez racjonalne sito normy, konstytuuje, moim zdaniem, dynamikę życia moralnego. To podejście bardziej bezpośrednie, mniej zależne od historii filozofii moralnej, także bardziej uważne na bogactwo analiz tekstualnych, zbyt pośpiesznie zamkniętych w szkolnych kategoriach, jak moralność teleologiczna czy moralność deontologiczna, wysuwa się na pierwszy plan w badaniu etyk stosowanych, którym poświęcam się dzisiaj.

Podam dwa przykłady etyki stosowanej: etykę medyczną i etykę prawniczą. Pierwsza jest wynikiem potrzeby troski wywołanej cierpieniem. Druga, w formie karnej, zajmuje się istnieniem konfliktów i koniecznością zapewnienia im bezstronnego rozstrzygnięcia. Jedna i druga są naznaczone przez szczególny akt sądzenia: diagnoza lekarska z jednej strony, wyrok sądowy z drugiej. Obie też stosują precyzyjne reguły 
moralne. Od strony medycznej reguły te przesądzają o umowie lekarskiej (pacte de soins), która wiąże dwie strony, pacjenta i lekarza, dzieleniem się tajemnicą lekarską, stosowaniem prawa do prawdy w zakresie diagnozy i terapii, wyrażeniem wyraźnej zgody na terapie ryzykowne. Wkład wiedzy medycznej i nauk biomedycznych zostaje przeszczepiony na pole tej etyki podstawowej, którą obejmuje umowa lekarska; tym samym, cały gmach prawa medycznego (bio-law) i publicznej polityki zdrowotnej uzupełnia gmach etyki medycznej; jednakowoż potrzeba opieki wywołana cierpieniem pozostaje najwyższym odniesieniem. Jak chodzi o wyrok sądowy, to jest on wynikiem ciągu istotnych działań procesu prowadzonego w murach sądowych. Są to operacje językowe, w których konfrontują się dwa roszczenia, oskarżenia i obrony; precyzyjne reguły procedury „skandują" dyskusję pomiędzy przeciwnymi stronami, umieszczoną „pod egidą” etyki dyskusji, która reguluje dostęp do głosu obu stron; wyrok zamyka tę ceremonię języka.

Podczas gdy umowa lekarska łączy lekarza i pacjenta, wyrok sądowy dzieli adwersarzy i umieszcza ich w odpowiedniej odległości; istotne zatem jest nie ukaranie, lecz stwierdzenie prawa, wypowiedzenie słowa sprawiedliwości w szczególnej sytuacji danej sprawy. Paralelizm pomiędzy etyką medyczną i etyką prawniczą znajduje swe przedłużenie $\mathrm{w}$ kombinacji między argumentacją i interpretacją, argumentacją opartą na abstrakcyjnych regułach rozumowania i interpretacją ważącą kontekst oceny i osobiste zaangażowanie decydenta, zarówno sędziego, jak i lekarza. Moje małe dziełko zatytułowane Le juste I (1995) ${ }^{14}$ zawiera kilka esejów poświęconych zasadniczo etyce prawniczej i jej przedłużeniu w dziedzinie karnej wraz z trudną problematyką więziennictwa, biorąc pod uwagę resocjalizację więźniów, bez której kara pozostawałaby pozbawiona sensu.

Pozwolą Państwo, że zakończę ten przegląd przywołaniem mojego ostatniego dzieła, zatytułowanego La mémoire, l'histoire, l’oubli $(2000)^{15}$.

14 Tenże, Le just, Paris 1995.

15 Tenże, La mémoire, l'histoire, l'oubli, Paris 2000. Wydanie polskie: Pamięć, historia, zapomnienie, tłum. J. Margański, Kraków 2007. 
Jest ono efektem, podobnie jak wszystkie moje wcześniejsze dzieła, odkrycia i przebadania stałych problemów, pozostawionych jak dotąd bez rozwiązania. Tak było w przypadku Temps et récit, gdzie doświadczenie czasowe było bezpośrednio skonfrontowane $\mathrm{z}$ aktywnością narracyjną, nie zważając na ich zapośredniczenie podejmowane przez pamięć. Stąd to zapośredniczenie w pamięci pozostawało zagadką nie tylko nierozwiązaną, ale nawet nierozpoznaną. Była to zagadka obecności w umyśle obrazu rzeczy przeszłych i więcej nieobecnych. Ta zagadka obecności tego, co nieobecne (présence de l'abscence), streszcza wszystkie trudności właściwe dla doświadczenia zdolności przypominania. W ten sposób akt władzy przypominania dołączył do listy władz charakterystycznych dla tego, co wyżej określiłem jako „człowiek zdolny” (l’homme capable). Akt przypominania sobie i władza, która go umożliwia, znajdują się na skrzyżowaniu dwóch wielkich funkcji: wyobraźni, zwróconej w stronę fikcji (irréel) i pamięci w ścisłym znaczeniu, skierowanej ku rzeczywistości minionej, przeszłej. Wszystkie trudności, jakie się nagromadziły wokół pamięci, osiągają swoją kulminację w ustaleniu kryterium różnicy pomiędzy fikcją, uprzywilejowanymi obiektami mentalnymi wyobraźni oraz tym rodzajem nieobecności, który odróżnia pamiętaną przeszłość od wyobrażonej fikcji. Z tego względu doświadczenie rozpoznania (reconnaissance) może być utrzymane jako kryterium, w którym potwierdza się zdolność pamięci do przedstawiania przeszłości. Oczywiście, badanie wspomnienia w procesie przypominania sobie stwarza okazję do nadużyć, pomyłki czy błędu, do wszelkiego rodzaju rozczarowania, ale moment rozpoznania pozostaje najwyższym i niezastąpionym kryterium tego, co filozof Henri Bergson bardzo szczęśliwie nazwał przeżywaniem (survivance) lub odżywaniem (reviviscence) obrazów z przeszłości. Ten moment rozpoznania jest tak kluczowy, gdyż to w nim zbiegają się trzy problematy: pamięć, historia i zapomnienie.

Pamięć, która w rzeczywistości osiąga swoją najwyższą formę w rozpoznaniu, nie jest jedynie rozpoznaniem jakiejś rzeczy przeszłej, lecz rozpoznaniem samego siebie. To połączenie pomiędzy pamięcią i sobością (le soi) jest tak ścisłe, że pamięć mogła być rozważana jako kryterium par excellence tożsamości osobowej, rozciągniętej następnie na 
wszystkie formy tożsamości zbiorowej. Na drodze pamięci odkrywam $\mathrm{w}$ ten sposób pojęcie tożsamości narracyjnej, opracowane w Temps et récit, a które pozostaje odtąd zakorzenione w doświadczeniu mnemonicznym (mnémonique).

Co więcej, to doświadczenie przedstawiania sobie przeszłości w momencie rozpoznania wywołuje, w całej swej rozciągłości i radykalności, dobrze znany problem tropu, w sensie śladu pozostawionego przez przeżyte wydarzenie w pewnym momencie czasu, na jakimkolwiek nośniku, danym nam do odkodowania i interpretacji. Stąd owe ślady są trojakiego rodzaju: ślady materialne, czytelne w umyśle - ślady psychiczne bezpośrednio zawarte w przeżyciu obrazów - ślady pisane zebrane $\mathrm{w}$ archiwach i dołączone do wszelkich śladów dokumentarnych i monumentalnych, zebranych przez przeszłą aktywność ludzką. Ten ostatni rodzaj - ślady dokumentarne - umożliwiają przejście od pamięci do historii. Noszą one na sobie pierwsze ślady pisma, które gromadzą nieprzeciętne ślady językowe, będące ich świadectwami. Świadek mówi: „Byłem tam”, i dodaje: „Wierz mi albo nie”, oraz „Jeśli mi nie wierzycie, spytajcie kogoś innego". Ta potrójna deklaracja świadka umożliwia przejście nie tylko od pamięci do historii, ale do samego wnętrza historii, pomiędzy świadectwem ustnym a świadectwem pisanym. Z kolei świadectwo pisane generuje sytuację konkurencji między przeciwstawnymi świadectwami, przez co pojawiają się, na korzyść krytyki świadectwa, wszystkie operacje charakterystyczne dla historii naukowej jako jednej z nauk humanistycznych.

$\mathrm{Na}$ tej archiwalnej podstawie, usankcjonowanej przez ustanowienie dowodu dokumentarnego, wznosi się czysto wyjaśniająca faza historii. W tym obszarze wyjaśniania rozwijają się wszystkie sposoby rozumowania historycznego, stosujące formułę „ponieważ...” w odpowiedzi na pytanie „dlaczego?”, stawiane począwszy od poziomu dokumentów w ramach sprawdzania archiwów i badania wszelkich śladów pisanych i znaków materialnych. To na tym poziomie wyjaśniania historia staje się dyscypliną różną od wszelkich innych nauk humanistycznych, socjologii, antropologii, lingwistyki, psychologii, etologii etc. Na tym samym poziomie historia oddala się także od pamięci i od swojego kryterium 
rozpoznania na tyle, na ile to tylko możliwe. Historia angażuje się w tworzenie powiązań przyczynowych, w sensie bliskim do używanego w naukach przyrodniczych, i w wyjaśnianie rozumowe, stosowane w zwykłych sytuacjach rozmowy i życia bieżącego. Z tego względu nie należy przeciwstawiać „wyjaśniania” (expliquer) „rozumieniu” (comprendre), skoro wyjaśniać znaczy poszukiwać przyczyny, a rozumieć to poszukiwać motywu działania (raison d’agir). Kombinacja przyczyny i motywu działania tworzy się na rozmaite sposoby, w zależności od tego, czy rozważamy historię gospodarczą, historię społeczną, historię polityczną, historię kultury, czy już bardziej dokładnie historię przedstawień, która nadaje symboliczną strukturę wymianom między czynnikami społecznymi, w poszukiwaniu ich tożsamości indywidualnej lub zbiorowej.

Jednakże to na poziomie trzeciej fazy operacji historycznej, w fazie pisma historycznego, skąd historiografia czerpie swą nazwę, pojawia się na końcu drogi problematyka przedstawienia przeszłości, której początki zostały przypomniane $\mathrm{w}$ obszarze pamięci, w momencie rozpoznania wspomnienia. Ponieważ historia jest pozbawiona tego małego szczęścia rozpoznania, jest ona zmuszona do skompensowania nieobecności tego intuicyjnego momentu rozpoznania przez złożoną architekturę konstrukcji, mniej czy bardziej naukowych, mając na celu rekonstrukcję przeszłości, taką, jaką się ona wydarza. Ale rekonstrukcja przeszłości przez historię nigdy nie będzie mogła się zrównać z pojawieniem się wspomnienia w spontanicznym przywołaniu, $\mathrm{z}$ tym rzadkim skarbem marzycielskiej pamięci. Do takiej mozolnej rekonstrukcji przyczyniają się zasoby narracyjne, które historia dzieli $z$ innymi formami opowieści, opowiadaniami o rozmowie, a nade wszystko opowiadaniami fikcyjnymi, z tragediami, od starożytnych epopei aż po nowożytne powieści. Do tego zapośredniczenia narracyjnego dochodzą wszystkie figury retoryczne, badane przez Vico pod nazwą metafory, synekdochy, metonimii i ironii; wszystkie trudności i podstępy rozmowy są w ten sposób poddane próbie wyobrażenia historycznego, z całym ryzykiem uwiedzenia - tego niebezpiecznego horyzontu strategii perswazyjnej. Wszystkie problemy dostrzeżone w obszarze pamięci, w miejscu, gdzie wyobraźnia i pamięć ponownie się przecinają w zagadce obecności tego, 
co nieobecne, wszystkie te problemy pojawiają się u kresu drogi historiograficznej pod postacią konfrontacji między fikcją i historią. Ostatecznie to od zdolności odróżniania historii od fikcji zależy los przedstawiania przeszłości w historii. Stawka jest następująca: czy historia jest skłonna wnieść swój wymiar krytyczny do poszukiwań wierności pamięci i w ten sposób podnieść tę ostatnią do rangi prawdy w historii? Pytanie to pozostaje otwarte i wywołuje zamęt w naukach historycznych.

Z kolei przez te dwie kwestie pamięci i historii przepływa problem zapomnienia. Jedna i druga definiują się w rzeczywistości przez walkę z zapomnieniem.

Ta groźba zapomnienia uzależniona jest od pamięci i od historii ze względu na ślady, których różnorodność i złożoność dopiero co przypomnieliśmy, jako ślady umysłowe (empreinte corticale), ślady afektywne i ślady dokumentarne. Wszystkie one mogą być bowiem zniszczone, wymazane. Niebezpieczeństwo to ciąży nad całym przedsięwzięciem ocalenia, które tworzą razem historia i pamięć ze względu na minioną przeszłość, a która przecież była przeszłością żywą dawnych ludzi. Lecz niebezpieczeństwo zapomnienia ma także swoją drugą stronę: jak to potwierdzają cenne doświadczenia, np. niespodziewane pojawienie się wspomnień z dzieciństwa, które uważaliśmy za definitywnie utracone, a także metodyczne poszukiwanie śladów ukrytych w przeszłości, na którym opiera się psychoanalityczna metoda badania nieświadomości. Przeszłość, którą uważaliśmy za utraconą na zawsze, jest skłonna na nowo nawiedzić obecną świadomość: ostatecznie zapominamy mniej, niż sądzimy, czy się obawiamy. Ale kto wprowadzi równowagę pomiędzy tymi dwoma formami zapominania?

Tą nutą niezdecydowania pragnę zakończyć mój wykład. Czy zapominanie przez odkładanie do rezerwy będzie aż do naszej śmierci równie silne, co zapominanie przez zacieranie śladów?

tłum. Piotr Karpiński 


\section{Bibliografia}

1. Jervolino D., Paul Ricoeur. Une herméneutique de la condition humaine, Paris 2002.

2. Ricoeur P., De l'interprétation. Essai sur Freud, Paris 1965. Wydanie polskie: O interpretacji. Esej o Freudzie, tłum. M. Falski, Warszawa 2008.

3. Ricoeur P., Gabriel Marcel et Karl Jaspers. Philosophie du mystere et philosophie du paradoxe, Paris 1948.

4. Ricoeur P., Karl Jaspers et la Philosophie de l'existence, en collaboration avec M. Dufrenne, Paris 1947.

5. Ricoeur P., La mémoire, l'histoire, l'oubli, Paris 2000. Wydanie polskie: Pamięć, historia, zapomnienie, tłum. J. Margański, Kraków 2007.

6. Ricoeur P., La métaphore vive, Paris 1975.

7. Ricoeur P., Le conflit des interprétations. Essais d’herméneutique I, Paris 1969. Fragmenty dzieła ukazały się po polsku: Egzystencja i hermeneutyka. Rozprawy o metodzie, tłum. E. Bieńkowska, H. Bortnowska, S. Cichowicz i in., Warszawa 1985.

8. Ricoeur P., Le just, Paris 1995.

9. Ricoeur P., Philosophie de la volonté: I. Le volontaire et l'involontaire, Paris 1950.

10. Ricoeur P., Philosophie de la volonté: II. Finitude et culpabilité: 1. L'homme faillible, Paris 1960. 2. La symbolique du mal, Paris 1960. Po polsku ukazała się jak dotąd tylko druga część drugiego tomu Filozofii woli: Symbolika zła, tłum. S. Cichowicz, M. Ochab, Warszawa 1986.

11. Ricoeur P., Soi-même comme un autre, Paris 1990. Wydanie polskie: O sobie samym jako innym, tłum. B. Chełstowski, Warszawa 2005.

12. Ricoeur P., Témps et recit, $t$-1: L'intrigue et le récit historique, Paris 1983 . Wydanie polskie: Czas i opowieść, tom 1: Intryga i historyczna opowieść, tłum. M. Frankiewicz, Kraków 2008.

13. Ricoeur P., Témps et recit, $t$-2: La configuration dans le récit de fiction, Paris 1984. Wydanie polskie: Czas i opowieść, tom 2: Konfiguracja w opowieści fikcyjnej, tłum. J. Jakubowski, Kraków 2008.

14. Ricoeur P., Témps et recit, t-3: Le temps raconté, Paris 1985. Wydanie polskie: Czas i opowieść, tom 3: Czas opowiadany, tłum. U. Zbrzeźniak, Kraków 2008. 